\title{
Serum biochemical reference ranges for lambs from birth to 1 year of age in the tropics
}

\section{Intervalos de referência de bioquímicos séricos para cordeiros do nascimento a um ano nos trópicos}

\author{
Laura Ferrari Monteiro Varanis ${ }^{1}$; Erica Beatriz Schultz ${ }^{2 *}$; Karla Alves Oliveira ${ }^{1}$; \\ Luciano Fernandes Sousa ${ }^{3}$; Wendell Fernando Guimarães da Cruz ${ }^{4}$; \\ Gilberto de Lima Macedo Junior ${ }^{5}$
}

\section{Highlights}

Biochemical reference ranges for lambs in the tropics differ from international data.

Estimated lipoprotein ranges contribute to our understanding of metabolic changes.

The separated per animal category contributes to the accuracy of parameters.

\begin{abstract}
The study aimed to determine the biochemical reference ranges for lambs from birth to 1 year of age in the tropics. Data were obtained from experiments performed in several institutions and commercial farms using Santa Inês, Dorper, Lacaune, Morada Nova, Bergamacia and Suffolk lambs reared under different conditions (grazing, feedlot, semi-feedlot) from 2006 to 2017. Serum energy-, protein-, mineral-, and enzyme-related metabolites were evaluated. The metabolic energy profile included data from glucose, cholesterol, triglycerides, fructosamine, high-density lipoprotein cholesterol, low-density lipoprotein cholesterol, and very-low-density lipoprotein cholesterol; the metabolic protein profile included total protein, uric acid, urea, albumin, and creatinine; the metabolic mineral profile included data on calcium, phosphorus, and magnesium; and the metabolic enzymatic profile included the enzymes aspartate aminotransferase, gammaglutamyl transferase, alkaline phosphatase, and creatine kinase. The reference ranges were estimated using confidence intervals with a 95\% confidence level, and percentiles were estimated or bootstrapped nonparametrically when the data were not normally distributed. The serum biochemical reference ranges determined for lambs are strongly divergent from those established by one of the most cited books on the topic, especially considering the high serum urea and cholesterol concentrations and low levels of blood

1 M.e Veterinay Science, Federal University of Uberlândia, UFU, Uberlândia, MG, Brazil. E-mail: laura_ferrari@gmail. com; karla.alves.oliveira@hotmail.com

2 Prof ${ }^{\mathrm{a}} \mathrm{Dr}^{\mathrm{a}}$, Federal Rural University of Rio de Janeiro, UFRRJ, Seropédica, RJ, Brazil. E-mail: ericabeatrizschultz@ gmail.com

3 Prof. Dr., Federal University of Tocantins, UFTO, Araguaína, TO, Brazil. E-mail: luciano.sousa@mail.uft.edu.br

${ }^{4}$ M.e Animal Science, Federal University of Lavras, UFLA, Lavras, MG, Brazil. E-mail: wendell_fg@hotmail.com

5 Prof. Dr., UFU, Uberlândia, MG, Brazil. E-mail: gilbertomacedojr@gmail.com

* Author for correspondence
\end{abstract}

Received: July 28, 2020 - Approved: Dec. 09, 2020 
glucose observed. Therefore, the serum biochemical reference ranges for lambs from birth to 1 year of age in the tropics differ from international data, which consider adult sheep in temperate climate zones.

Key words: Energy profile. Metabolites. Protein profile. Sheep.

\section{Resumo}

Objetivou-se determinar as faixas de referência dos parâmetros bioquímicos para cordeiros desde o nascimento até a idade de um ano nos trópicos. Os dados foram obtidos a partir de experimentos realizados em diversas instituições e fazendas comerciais, utilizando cordeiros Santa Inês, Dorper, Lacaune, Morada Nova, Bergamacia e Suffolk criados em diferentes condições (pastejo, confinamento, semi-confinamento) de 2006 a 2017. Foram avaliados os metabólitos séricos relacionados à energia, proteína, minerais e vitaminas. O perfil metabólico incluiu dados de glicose, colesterol, triglicerídeos, frutosamina, lipoproteína de alta densidade, lipoproteína de baixa densidade e lipoproteína de densidade muito baixa; o perfil metabólico proteico incluiu proteína total, ácido úrico, ureia, albumina e creatinina; o perfil mineral os dados sobre cálcio, fósforo e magnésio; e o perfil enzimático as enzimas aspartato aminotransferase, gamaglutamil transferase, fosfatase alcalina e creatina quinase. As faixas de referência foram estimadas usando intervalos de confiança com nível de confiança de 95\%, e os percentis foram estimados por métodos não paramétricos de reamostragem quando não apresentavam distribuição normal. Os intervalos bioquímicos séricos de referência para cordeiros determinados são fortemente divergentes dos estabelecidos por um dos livros mais citados sobre o tema, principalmente considerando as altas concentrações séricas de ureia e colesterol e baixos níveis de glicose observados no sangue. Portanto, as faixas bioquímicas séricas de referência para cordeiros do nascimento a um ano nos trópicos diferem dos dados internacionais, que contemplam ovelhas adultas em países temperados.

Palavras-chave: Metabólitos. Ovinos. Perfil energético. Perfil proteico.

\section{Introduction}

Blood serum biochemical values are essential tools in the diagnosis, treatment, and prediction of diseases in livestock (Njidda, Shuai, \& Isidahomen, 2014). Although it is possible to find reference ranges for several metabolites of sheep in the literature, most data are based on sheep raised under temperate conditions, with no distinction between animal categories. It is known that blood serum biochemical values vary according to several factors, including age, physiological status, and environmental temperature, making the interpretation of metabolic profiles complex (Peixoto \& Osório, 2007; González \& Scheffer, 2009).
The development of a newborn lamb into a ruminant comprises anatomical, physiological, and metabolic changes in the gastrointestinal tract, namely in the rumen, reticulum, and abomasum. As soon as they are born, lambs are fed exclusively on natural maternal milk, and the rumen and reticulum encompass approximately half the size of the abomasum. At this stage, as the rumen is not functional, the suckled milk goes straight to the abomasums (Bacila, 2003).

The supply of forage and concentrates during the transition from pre-ruminant to functional ruminant is essential to boost rumen development. Concentrate feeds stimulate the vascularization and proliferation of mucosal epithelial cells, leading to an increase in papillary 
density throughout the ruminal epithelium, while fiber intake stimulates ruminal growth, development, and motility, maximizing rumen digestive and absorptive capacity (Astutiet, Baba, \& Wibawan, 2012).

In lambs, the plasma levels of energy metabolites such as glucose and triglycerides tend to decrease with advancing age. After weaning, there is a significant reduction in glucose levels due to changes in diet and energy metabolism, as reported by Gregory et al. (2009), whereas the use of energy for muscle mass deposition is responsible for decreased levels of serum triglycerides in lambs (Santos et al., 2015).

The serum protein concentration is low at birth and increases rapidly after colostrum ingestion. However, it decreases during the first month, especially the globulin fraction (Loste et al., 2008). Serum albumin levels respond similarly to the serum protein concentration in lambs. On the other hand, the uric acid concentration is high during the suckling phase compared with the post-weaning period due to the introduction of concentrate feeds in the diet (D'angelino, Ishizuka, Ribeiro, Tucci, \& Birgel, 1990; E. R. R. Silva et al., 2017).

Given several adaptations that lambs experience during the yearling phase, their metabolic levels may differ from those of adult sheep. This factor was not considered by numerous studies aimed at defining references ranges for sheep, which do not take into account differences related to the animal category.

Thus, the aim of this study was to determine the biochemical reference ranges for lambs from birth to 1 year of age in the tropics, including serum energy-, protein-, enzyme-, and mineral-related metabolites.

\section{Material and Methods}

Data from a variety of metabolites were obtained from experiments performed in several institutions (Federal University of Uberlândia, Federal University of Minas Gerais, Federal University of Lavras, Federal Rural University of Rio de Janeiro, Federal University of Tocantins) and commercial farms using Santa Inês, Dorper, Lacaune, Morada Nova, Bergamacia and Suffolk lambs reared under different conditions, including 12 grazing studies with 1200 lambs, 32 feedlot studies with 2000 lambs, and 16 semi-feedlot studies with 600 lambs, using collective and/ or individual pens and metabolic cages, from 2006 to 2017. Most management practices are commercially adopted in Brazil and other tropical countries; the use of metabolic cages is essential in studies of digestibility and feeding behavior. All handling practices followed the recommendations of the European Council Directive 2010/63/EU for the protection of animals used for scientific purposes. Data from ewes showing any clinical manifestations were removed. Data were obtained considering lambs from birth to 12 months of age.

The metabolic energy profile included data on glucose, cholesterol, triglycerides, fructosamine, HDL (high-density lipoprotein cholesterol), LDL (low-density lipoprotein cholesterol), and VLDL (very-low-density lipoprotein cholesterol); the metabolic protein profile included the metabolites total protein (TP), uric acid, urea, albumin, and creatinine; the metabolic mineral profile included data on calcium $(\mathrm{Ca})$, phosphorus $(\mathrm{P})$, and magnesium (Mg); and the metabolic enzymatic profile included the enzymes AST (aspartate aminotransferase), GGT (gamma-glutamyl transferase), ALP (alkaline phosphatase), 
and creatine kinase (CK). The analyses were performed on the Bioplus 2000 and PKL-125 devices (MH-Lab) using commercial Labtest ${ }^{\circledR}$ reagents specific for each metabolite. The VLDL and LDL values were obtained using the equations proposed by Friedewald, Levy and Fredrickson (1972) based on the total serum cholesterol, $\mathrm{HDL}$, and triglycerides: $V L D L=T G / 5 ; L D L=T C-H D L-V L D L$, where: $V L D L$ is very-low-density lipoprotein; $T G$ is triglycerides; $L D L$ is low-density lipoprotein; $T C$ is total cholesterol, and $H D L$ is high-density lipoprotein.

Reference intervals were estimated using the software RefVal 4.11 (Solberg, 2006). Dixon's test was used to identify and remove outliers. The Shapiro-Wilk test was used to verified data normality. The confidence intervals and percentiles were estimated using the nonparametric bootstrap method when data were not normally distributed. Data were normalized to the $P$ level, and the reference intervals were estimated parametrically. A 95\% confidence level was used.

The physiological reference ranges determined in this study were compared with established reference intervals for serum biochemical parameters presented by Kaneko, Harvey and Bruss (2008), which is one of the most cited books with about 5,770 citations accord to Google Scholar Citations.

\section{Result and Discussion}

Data relative to the physiological reference ranges for energy-, protein-, mineral-, and enzyme-related metabolites in lambs reared under tropical conditions, as well as sample size and the references range for comparison are shown in Table 1.

Relative to the reference range established by Kaneko et al. (2008), the reference interval for serum glucose (33$98.1 \mathrm{mg} \mathrm{dL}^{-1}$ ) was wider: the lower reference limit was 34\% lower and the upper reference limit 22.6\% higher. The reference intervals for serum cholesterol (15-139.9 $\mathrm{mg} \mathrm{dL}^{-1}$ ) included as the lower limit a minimum value $28 \%$ lower and an upper limit value 84\% higher than that established by Kaneko et al. (2008). Reference intervals for serum triglycerides $(5-78 \mathrm{mg}$ $\left.\mathrm{dL}^{-1}\right)$ and fructosamine (111-413.61 $\left.\mu \mathrm{mol} \mathrm{L}^{-1}\right)$ included as the maximum reference values $160 \%$ and $137.7 \%$ higher than the upper limit defined by Kaneko et al. (2008), respectively. Reference intervals for serum HDL (13-79 mg $\left.\mathrm{dL}^{-1}\right)$, LDL (0.80-83.36 $\mathrm{mg} \mathrm{dL}^{-1}$ ) and VLDL (1$17.4 \mathrm{mg} \mathrm{dL}^{-1}$ ) were established in this study for lambs but were not determined by Kaneko et al. (2008). 


\section{Table 1}

Serum biochemical reference ranges for lambs from birth to yearling reared under tropical conditions, including energy-, protein-, mineral- and enzyme-related metabolites

\begin{tabular}{|c|c|c|c|c|}
\hline Metabolites & Unit & $\mathrm{SS}^{1}$ & $\begin{array}{l}\text { Reference ranges } \\
\text { (our study) }\end{array}$ & $\begin{array}{l}\text { Reference ranges } \\
\text { (Kaneko et al., 2008) }\end{array}$ \\
\hline \multicolumn{5}{|c|}{ Energy-related metabolites } \\
\hline Glucose & $\mathrm{mg} \mathrm{dL}^{-1}$ & 2194 & $33-98.1$ & $50-80$ \\
\hline Cholesterol & $\mathrm{mg} \mathrm{dL}^{-1}$ & 2795 & $15-139.9$ & $52-76$ \\
\hline Triglycerides & $\mathrm{mg} \mathrm{dL}^{-1}$ & 2566 & $5-78$ & $9-30$ \\
\hline Fructosamine & $\mu \mathrm{mol} \mathrm{L}{ }^{-1}$ & 1546 & $111-413.61$ & $170-174$ \\
\hline $\mathrm{HDL}^{2}$ & $\mathrm{mg} \mathrm{dL}^{-1}$ & 1007 & $13-79$ & $\mathrm{ND}^{5}$ \\
\hline LDL $^{3}$ & $\mathrm{mg} \mathrm{dL}^{-1}$ & 746 & $0.80-83.36$ & $\mathrm{ND}^{5}$ \\
\hline VLDL $^{4}$ & $\mathrm{mg} \mathrm{dL}^{-1}$ & 2566 & $1-17.4$ & $\mathrm{ND}^{5}$ \\
\hline \multicolumn{5}{|c|}{ Protein-related metabolites } \\
\hline Total protein & $\mathrm{g} \mathrm{dL}^{-1}$ & 2621 & $3.10-11.4$ & $6-7.9$ \\
\hline Uric acid & $\mathrm{mg} \mathrm{dL}^{-1}$ & 2623 & $0-2.9$ & $0-1.9$ \\
\hline Urea & $\mathrm{mg} \mathrm{dL}^{-1}$ & 2652 & $12.8-100$ & $17-43$ \\
\hline Albumin & $\mathrm{g} \mathrm{dL}^{-1}$ & 2562 & $1.12-5.38$ & $2.4-3.0$ \\
\hline Creatinine & $\mathrm{mg} \mathrm{dL}^{-1}$ & 2598 & $0.40-1.80$ & $1.2-1.9$ \\
\hline \multicolumn{5}{|c|}{ Mineral-related metabolities } \\
\hline Calcium & $\mathrm{mg} \mathrm{dL}^{-1}$ & 1828 & $4.6-14.22$ & $11.5-12.8$ \\
\hline Phosphorus & $\mathrm{mg} \mathrm{dL}^{-1}$ & 1813 & $4.21-16.6^{*}$ & $5-7.3$ \\
\hline Magnesium & $\mathrm{mg} \mathrm{dL}^{-1}$ & 1915 & $1.07-4.66$ & $2.2-2.8$ \\
\hline \multicolumn{5}{|c|}{ Enzyme-related metabolites } \\
\hline AST $^{6}$ & $U L^{-1}$ & 2312 & $47-353.5$ & $60-280$ \\
\hline $\mathrm{GGT}^{7}$ & $U L^{-1}$ & 2253 & $31-154$ & $20-52$ \\
\hline $\mathrm{CK}^{8}$ & $U L^{-1}$ & 284 & $73-536$ & $8.1-12.9$ \\
\hline ALP $^{9}$ & $U L^{-1}$ & 2297 & $58-727.7$ & $68-387$ \\
\hline
\end{tabular}

1SS - Sample size; ${ }^{2} \mathrm{HDL}$ - high-density lipoprotein; ${ }^{3} \mathrm{LDL}$ - low-density lipoprotein; ${ }^{4} \mathrm{VLDL}$ - very-low density lipoprotein; ${ }^{5}$ Not determined, ${ }^{6} \mathrm{AST}$ - aspartate aminotransferase; ${ }^{7} \mathrm{GGT}$ - gamma-glutamyl transferase; ${ }^{8} \mathrm{Creatine}$ kinase; ${ }^{9} \mathrm{ALP}$ Alkaline phosphatase. *Parametric data.

In an assay with Indonesian thintailed growing sheep fed with tropical browse plants, Astuti et al. (2012) reported values of blood glucose of $37.50 \mathrm{mg} \mathrm{dL}-1$. According to Rahman et al. (2018), blood glucose levels in indigenous sheep (Ovies aries) in Bangladesh less than six months old and reared under semiintensive conditions ranged from 35.6 to 53.4 $\mathrm{mg} \mathrm{dL}^{-1}$. Njidda et al. (2014) observed means for blood glucose levels of 43.2 and $39.6 \mathrm{mg}$ $\mathrm{dL}^{-1}$ in male and female Balami lambs reared in Northern Nigeria, respectively. Mahjoubi et al. (2015) evaluating Afshari lambs under thermo neutral conditions, reported a blood glucose level of $88.9 \mathrm{mg} \mathrm{dL}^{-1}$; Al-Haidary et al. (2012) found a blood glucose level of $95.07 \mathrm{mg} \mathrm{dL}^{-1}$ in 
12-month-old Nadji sheep during the summer period in Saudi Arabia.

The studies mentioned above agree with our reports that the lower range for blood glucose levels in lambs from 0 to 12 months is below the lower boundary reported by Kaneko et al. (2008) of $50 \mathrm{mg} \mathrm{dL}^{-1}$ and above the upper limit of $80 \mathrm{mg} \mathrm{dL}^{-1}$. Therefore, the blood glucose ranges (33-98.1 $\mathrm{mg} \mathrm{dL}^{-1}$ ) are broader than those cited in the literature. On the other hand, Maurya, Sejian and Naqvi (2013) found an average glucose level of $59.2 \mathrm{mg} \mathrm{dL}^{-1}$ when evaluating the blood metabolites of native Malpura lambs in the hot semi-arid tropics of India. A study conducted by Carlos et al. (2015) using Morada Nova lambs aged up to 6 months in Brazil reported a blood glucose level of 64.3 $\mathrm{mg} \mathrm{dL}^{-1}$. Oramari, Bamerny and Zebari (2013), studying Karadi, Awassi, and Naimy sheep aged 8 to 10 months in Iraq, observed a mean blood glucose level of $58.2 \mathrm{mg} \mathrm{dL}^{-1}$. Those values are within both reference intervals analyzed.

In an assay with male and female Balami lambs, Njidda et al. (2014) observed means for blood cholesterol of 32.4 and $36.0 \mathrm{mg} \mathrm{dL}^{-1}$, respectively. The mean blood cholesterol was $45.62 \mathrm{mg} \mathrm{dL}^{-1}$ in Karadi, Awassi and Naimy lambs (Oramari et al., 2013) and $36.9 \mathrm{mg} \mathrm{dL}^{-1}$ in hair lambs fed ad libitum (Pereira et al., 2018). On the other hand, Santos et al. (2015) reported mean blood cholesterol of $101.6 \mathrm{mg} \mathrm{dL}^{-1}$ in 45-day-old hair lambs, and Carlos et al. (2015) observed a value of $97.3 \mathrm{mg} \mathrm{dL}^{-1}$ for the same parameter in Morada Nova lambs. Such results are within the range defined in this study but do not agree with physiological values proposed by Kaneko et al. (2008). Principal sources of cholesterol are exogenous cholesterol derived from dietary sources, particularly from dams' milk, whereas endogenous cholesterol is synthesized from acetyl-coenzyme $A$ in the liver (González \& Scheffer, 2009). Lambs tend to exhibit reduced cholesterol concentrations with advancing age due to changes in diet (Souza et al., 2020). Our results show greater variability (15-139.9) in lambs at birth up to 1 year in the tropics, which is related to diet or a greater need for body fat deposition.

Santos et al. (2015) reported a mean serum triglyceride concentration of $34.7 \mathrm{mg}$ $\mathrm{dL}^{-1}$ in 100-day-old Santa Inês hair lambs. In contrast, Astuti et al. (2012) reported triglyceride levels of $70.0 \mathrm{mg} \mathrm{dL}^{-1}$ in Indonesian thin-tailed growing sheep fed with tropical browse plants. Those values are below and above, respectively, the reference interval recommended by Kaneko et al. (2008) but still within the ranges defined in our study. When fed low-energy feedstuffs during the growing phase, lambs obtain energy from triglycerides for muscle deposition, which results in low blood concentrations of this metabolite (Santos et al., 2015). Low-energy feedstuffs and low-quality forage are common during the dry season of the year in tropical conditions, and supplementation strategies are being researched (Oliveira Franco et al., 2017). This explains the variations found in the range of serum triglyceride concentrations.

Six-month-old, crossbred lambs showed a mean plasma fructosamine concentration of $290.41 \mu \mathrm{mol} \mathrm{L} \mathrm{L}^{-1}$ (Gouveia et al., 2015). This value is above that referenced in the literature but is within the range defined in this study. For cases of hyperglycemia, these values are justified because of fructosamine is a stable ketoamine compound formed when a glucose molecule attaches non-enzymatically with amino groups of proteins (Stear etal., 2001). Fructosamine may be a suitable criterion for long-term nutritional status in livestock, since its concentration is considered an indicator of 
glycemia over a 2-3-week period (Chon, Lee, Fraterrigo, Pozzilli, \& Choi, 2013), as well as indicating average protein concentrations in plasma (Stear et al., 2001).

Although Kaneko et al. (2008) did not determine high- and low-density lipoprotein cholesterol concentrations in their study, they highlighted the importance HDL and LDL as the lipoproteins responsible for the transport of cholesterol from the tissues to the liver and vice versa. In an assay with 5-month-old growing lambs grazing on Massai grass in Brazil, Mugabe et al. (2017) reported mean HDL and LDL concentrations of 21.24 and 14.58 $\mathrm{mg} \mathrm{dL}^{-1}$, respectively, similar to the HDL value of $21.8 \mathrm{mg} \mathrm{dL}^{-1}$ in 3-month-old lambs raised under an intensive system in India (Babu, Suryanarayana, Raghava, \& Asha Latha, 2018). In younger Dorper lambs (15-30 days old), Cruz et al. (2017) observed mean HDL and LDL concentrations of 60.4 and $41.8 \mathrm{mg} \mathrm{dL}^{-1}$, respectively, as a result of a milk-based diet since the primary energy source in milk is in the form of lipids. All of these values are within the estimates presented in Table 1.

As VLDL is the lipoprotein that transports triglycerides, both present similar patterns. Lambs fed low-energy feedstuffs need to use the energy stored as triglycerides for muscle deposition, and consequently, VLDL for its transport (Sejian et al., 2017). In an assay with 90-day-old crossbred (Santa Ines $\times$ Dorper) ram lambs, Van Cleef, Almeida, Perez, Carvalho and Paschoaloto (2016) reported a mean VLDL concentration of $2.5 \mathrm{mg} \mathrm{dL}^{-1}$, whereas Cruz et al. (2017) observed a mean VLDL concentration of $6.50 \mathrm{mg} / \mathrm{dL}$ in male and female Dorper lambs (15-121 days old). The concentration of VLDL tends to until increase the first 25 days and to decrease as weaning begins.
All protein-related metabolites had wider reference intervals than those established by Kaneko et al. (2008). For example, the upper reference limit of the interval for serum TP (3.10-11.4 $\left.\mathrm{g} \mathrm{dL}^{-1}\right)$ was $44.3 \%$ higher in the present study. In the same way, the reference interval for serum uric acid (0-2.9 $\left.\mathrm{mg} \mathrm{dL}^{-1}\right)$ had an upper reference limit $52.6 \%$ higher than that observed in the study of Kaneko et al. (2008). For serum urea (12.8$\left.100 \mathrm{mg} \mathrm{dL}^{-1}\right)$, the upper reference limit was $132 \%$ higher than the reported by Kaneko et al. (2008), whereas for serum albumin (1.12-5.38 g $\mathrm{dL}^{-1}$ ) the minimum reference value was $53.3 \%$ lower, and the maximum reference value was $79.3 \%$ higher compared with the values found by Kaneko et al. (2008). Reference intervals for serum creatinine $\left(0.40-1.80 \mathrm{mg} \mathrm{dL}^{-1}\right)$ included as the lower limit a minimum value $65 \%$ lower than that established by Kaneko et al. (2008).

R. G. da Silva, Paranhos and Sobrinho (1992) reported a TP concentration of $5.63 \mathrm{~g}$ $\mathrm{dL}^{-1}$ in unshorn Polwarth lambs younger than 12 months under low $\left(10.5-25^{\circ} \mathrm{C}\right)$ and high $\left(25-46.5{ }^{\circ} \mathrm{C}\right)$ environmental temperatures in Brazil. In an assay with Santa Ines sheep less than 6 months old, Meira Rizzo, Benesi and Gregory (2009) observed a mean TP concentration of 5.80 , which is similar to that found by Pereira et al. (2018) in 60-day-old hair lambs (Santa Ines) fed ad libitum (5.78 $\left.\mathrm{g} \mathrm{dL}^{-1}\right)$. Especially for Santa Inês lambs, the mentioned TP values were below that recommended by Kaneko et al. (2008) of $6 \mathrm{~g} \mathrm{dL}^{-1}$ but still within the range defined in this study. Besides the breed effect, it is also important to highlight that all lambs were healthy, thus variations can also be explained by dietary differences, since TP concentrations are responsive to nutritional influences (Sejian et al., 2017) and by the lower efficiency of amino acid utilization 
in young animals compared with adult sheep. Mammals have low TP concentrations at birth, which increase after the intake of colostrum and milk. It decreases at 1-5 weeks of age but increases again at 6-12 months of age (AbdelFattah, Hashem, Shaker, Ellamei, \& Amei, 2013). The influence of age on TP concentration was also reported in non-tropical sheep breeds, such as Chios (Roubies et al., 2006) and Merino landschaf (Antunović, Šperanda, \& Steiner, 2004). Higher protein concentrations $(10.24 \mathrm{~g} / \mathrm{dL})$ were found in 90-day-old Bharat Merino and Malpura lambs in India (Tripathi, Mondal, \& Karim, 2008) and even though this value is approximately $30 \%$ higher than the physiological values proposed by Kaneko et al. (2008), it is still within the range defined in this study. Therefore, the data suggest that our findings are representative of lambs raised under tropical conditions, regardless of breed and diet.

Serum uric acid levels indicate recent ruminal metabolism as they increase according to feed intake and nutritional quality of the feed. These factors also affect the number of microorganisms in the rumen. In an assay using Santa Inês hair lambs from birth to 90 days old, Santos, Macedo, Silva, Sousa and Andrade (2017) reported a serum uric acid concentration of $0.16 \mathrm{mg} \mathrm{dL}^{-1}$.

For blood urea nitrogen, physiological values above the proposed by Kaneko et al. (2008) were found in Brazilian studies. Carlos et al. (2015), using Morada Nova lambs aged up to 6 months reported a blood urea nitrogen (BUN) of $56.8 \mathrm{mg} \mathrm{dL}^{-1}$, whereas Vivian et al. (2017) observed a BUN of $70.52 \mathrm{mg} \mathrm{dL}^{-1}$ in Dorper crossbred lambs at the end of the finishing phase. On the other hand, BUN reached $14.00 \mathrm{mg} \mathrm{dL}^{-1}$ in male Yankasa lambs in Nigeria (Aliyu, Maigandi, Muhammad, \& Gaba, 2012). The amount of dietary protein interferes with BUN levels (Schroder, Schoneberger, Rodehutscord, Pfeffer, \& Breves, 2003). It is known that approximately $70 \%$ of protein is converted to ammonia in the rumen to be then used by ruminal microorganisms for the synthesis of structural proteins. Therefore, rumen- degradable protein levels are directly related to the rumen ammonia concentration. A considerable portion is absorbed and, upon reaching the liver, converted to urea. Thus, the BUN concentration reflects changes in rumen ammonia production (Aliyu et al., 2012). In addition, urea is correlated with gluconeogenic amino acid precursors in the liver. It is essential to highlight the considerable excretion of urea in saliva. A significant amount of urea is directed to the rumen, where it undergoes urease-driven hydrolysis, yielding ammonia and carbon dioxide. Ammonia is used as a source of non-protein nitrogen by ruminal microorganisms for the synthesis of microbial proteins (Bacila, 2003). In turn, they are hydrolyzed and incorporated by protozoa and bacteria, which will be degraded in the abomasum and intestine. These derived amino acids are absorbed by the portal vein, reach the liver, and are incorporated into animal proteins.

Albumin is recognized as the most representative parameter of the protein status in livestock (Shetaewi \& Ross, 1991). Considering that albumin levels in serum are considerably stable, changes are only observed in periods greater than 30 days. For lambs raised in the tropics, all values found in the literature were above that recommended by Kaneko et al. (2008) but still within the physiological ranges of the present study. In an assay with Indonesian thin-tailed growing sheep fed with tropical browse plants, Astuti 
et al. (2012) reported albumin values of $4.28 \mathrm{~g}$ $\mathrm{dL}^{-1}$. Serum albumin concentrations reached $3.59 \mathrm{~g} \mathrm{dL}^{-1}$ in 90-day-old Bharat Merino, and Malpura lambs in India (Tripathi et al., 2008) and $3.96 \mathrm{~g} \mathrm{dL}^{-1}$ in feedlot Dorper crossbred lambs in Brazil (Vivian et al., 2017).

For Santa Inês hair lambs up to 6 months old, serum creatinine levels obtained in the literature were 0.85 and $0.92 \mathrm{mg} \mathrm{dL}^{-1}$ (Santos et al., 2017; Lima et al., 2012). These studies agree with our reports that the lower range for serum creatinine levels in lambs raised under tropical conditions is below that stated by Kaneko et al. (2008) of $1.2 \mathrm{mg}$ $\mathrm{dL}^{-1}$. Creatinine is a non-protein nitrogenous compound derived from the catabolism of phosphocreatine through a non-enzymatic, irreversible, constant reaction (Samra \& Abcar, 2012). Creatinine levels are poorly affected by nutrition, although they are increased by the degradation of protein reserves to meet the energy demand (Kaneko et al., 2008). Since its concentrations are associated with the protein status in ruminants and are correlated with muscle deposition (Samra \& Abcar, 2012), creatinine levels tend to increase as animals grow older (Pereira et al., 2018). Then, it is probable that non-specialized meat sheep breeds, like most breeds raised in the tropics, have lower levels of serum creatinine, evidencing the importance of establishing proper serum biochemical reference ranges for lambs raised in the tropics.

Relative to mineral-related metabolites, the defined range for $\mathrm{Ca}$ was more extensive than the reference range established by Kaneko et al. (2008), with lower and upper limits $60 \%$ and $11 \%$ higher, respectively. Reference intervals for $\mathrm{P}$ were also more comprehensive, with a lower reference limit $15.8 \%$ lower and an upper limit $127 \%$ higher than that recommended by Kaneko et al. (2008). For $\mathrm{Mg}$, the defined reference range included as the upper limit a value $66 \%$ higher than that recommended by Kaneko et al. (2008).

Calcium homeostasis is subject to tight control (Kaneko et al., 2008). Cruz et al. (2017) observed a mean serum $\mathrm{Ca}$ concentration of $10.8 \mathrm{~g} \mathrm{dL}^{-1}$ in male and female Dorper lambs (15-121 days old). In an assay using 90-dayold Santa Inês hair lambs, Santos et al. (2017) reported a mean serum $\mathrm{Ca}$ concentration of $9.58 \mathrm{mg} \mathrm{dL}^{-1}$. Sarwar and Shahzad (2011) also reported a mean serum Ca concentration below than that recommended by Kaneko et al. (2008) but still within the range defined in our study, of $8.6 \mathrm{mg} \mathrm{dL}^{-1}$ in male Kajli lambs 6 months of age. On the other hand, Pereira et al. (2018) observed a mean serum Ca concentration of $13.1 \mathrm{mg} \mathrm{dL}^{-1}$ in 14-week-old Santa Ines lambs. Calcium is highly abundant in the animal's body, although its intestinal absorption decreases with advancing age. Vitamin D in the form of cholecalciferol (D3) is of great importance in the absorption of Ca by inducing $\mathrm{Ca}$ binding to proteins in the intestinal mucosa, preventing Ca reabsorption by the organism (Bacila, 2003). Low levels of albumin may also indicate a decreased $\mathrm{Ca}$ concentration, since this protein is responsible for the transport of $\mathrm{Ca}$ in plasma (Ribeiro et al., 2003).

Phosphorus is the second most abundant mineral in the animal's body. Phosphorus in the phosphate form participates in the formation of the bone matrix and its mineralization along with $\mathrm{Ca}$. This mineral is also crucial for ruminal microorganisms, and the metabolism of lipids and glycans (González, 2000). Phosphorus levels depend on the 
amount recycled through saliva and absorbed by the intestine; the higher the $P$ intake, the greater the amount of $P$ metabolized in the intracellular space, resulting in decreased $P$ in plasma (González, 2000; Ribeiro et al., 2003). Pereira et al. (2018) observed a mean serum $P$ concentration of $7.89 \mathrm{mg} \mathrm{dL}^{-1}$ in 23-week-old Santa Ines lambs. In an assay using Santa Inês hair lambs from birth to 90 days old, Santos et al. (2017) reported mean serum $P$ concentration of $12.06 \mathrm{mg} \mathrm{dL}^{-1}$. Cruz et al. (2017) observed a mean serum $P$ concentration of $8.80 \mathrm{mg}$ $\mathrm{dL}^{-1}$ in male and female Dorper lambs (15-121 days old). The serum $P$ concentrations of the mentioned studies were above the reference ranges determined by Kaneko et al. (2008) but within the ranges defined in our study.

Magnesium is the fourth most abundant element in the animal's body and is associated with $\mathrm{Ca}$ and $\mathrm{P}$ in tissues. Magnesium plays an essential role in the growth and development of livestock animals as an enzymatic cofactor of energy reactions. This mineral is not subject to homeostatic control; therefore, the diet is the most important source of $\mathrm{Mg}$ (Ribeiro et al., 2003; Borburema et al., 2012). In an assay using Santa Inês hair lambs with 19 weeks of age, Pereira et al. (2018) reported mean serum magnesium concentration of $1.72 \mathrm{mg}$ $\mathrm{dL}^{-1}$, a value similar to that found by Sarwar and Shahzad (2011) of $2.00 \mathrm{mg} \mathrm{dL}^{-1}$ in male Kajli lambs of six months old. Cruz et al. (2017) observed a mean Mg concentration of $3.00 \mathrm{mg} /$ $\mathrm{dL}$ in male and female Dorper lambs (15-121 days old), while the and $3.76 \mathrm{mg} \mathrm{dL}^{-1}$ in Awassi lambs with four months age (Abdelrahman, 2012).

Intervals for serum AST (47 - $353.5 \mathrm{U}$ $\mathrm{L}^{-1}$ ) included as the maximum reference a value $26.25 \%$ higher than that established by Kaneko et al. (2008), whereas reference intervals for
GGT (31 - $154 \mathrm{U} \mathrm{L}^{-1}$ ) included as the minimum and maximum reference values 55\% lower and $100 \%$ higher than the ranges defined by Kaneko et al. (2008), respectively. For creatine kinase (73-536 $\mathrm{U} \mathrm{L}^{-1}$ ), the defined reference range exceeded the values of Kaneko et al. (2008), since the lower limit established in this study was almost five times higher. The reference interval for serum ALP (58-727.7 $U^{-1}$ ) included as the upper limit a value $88 \%$ higher than that established by Kaneko et al. (2008).

The concentration of aspartate aminotransferase is usually high during the first days of life due to the higher intake of colostrum, a high source of fat. Moreover, high AST levels may indicate the development of secondary hepatocellular lesions due to the excessive mobilization of lipids (Santos et al., 2015). In the present study, although the upper limit defined was $26 \%$ higher than that defined by Kaneko et al. (2008), the animals evaluated did not show significant alterations in liver function; therefore, the obtained range for AST is adequate for healthy lambs in this animal category.

GGT is an enzyme found in the cell membrane of several tissues, such as the liver, kidneys, and intestines, with a higher concentration in the epithelium of the bile ducts and renal tubular cells (Santos et al., 2015). Borburema et al. (2012) stated that decreases in GGT concentration could occur under feed restriction conditions because this enzyme is responsible for the degradation of glutathione, which serves with a source of cysteine for protein synthesis, mainly albumin. On the other hand, the increase in GGT levels may be associated with hepatic disorders in animals (Santos et al., 2015). 
Kowalski, Sousa, Monteiro, Fernandes and Silva (2013) reported that CK concentrations remain constant within the first 72 hours after lambing and indicate that the liver is undergoing morpho-functional adaptation depending on development. As this enzyme is used to investigate an increase in physical effort and contusions, such results indicate that animal transportation has likely resulted in tissue lesions. In addition, increased CK may increase muscle mass in growing sheep (Carlos et al., 2015). The predominance of extensive breeding, Brazilian transport conditions favorable to tissue lesions, and the demand for growth justify the greater interval observed in $\mathrm{CK}$ in lambs raised in the tropics.

Elevated concentrations of alkaline phosphatase are mainly correlated with liver disease (Santos et al., 2015), highlighting that lambs in tropical regions have a higher tolerance to elevation without showing clinical signs compared to Kaneko et al. (2008). As demonstrated by Gouveia et al. (2015), it is necessary to consider that the reference values found in the literature were derived from lambs reared under different environmental and nutritional conditions, which reduces the accuracy of comparison.

\section{Conclusion}

The serum biochemical reference ranges for lambs determined in our study are strongly divergent from those established by one of the most cited books on the topic. Therefore, the serum biochemical reference ranges for lambs from birth to 1 year of age in the tropics differ from international data, which consider sheep raised in temperate climate zones.

\section{Acknowledgment}

We acknowledge the support received by the Conselho nacional de desenvolvimento científico e tecnológico (CNPq), Federal University of Uberlândia, Federal University of Minas Gerais, Federal University of Lavras, Federal Rural University of Rio de Janeiro, and Federal University of Tocantins.

\section{References}

Abdel-Fattah, M. S., Hashem, A. L. S., Shaker, Y. M., Ellamei, A. M., \& Amer, H. Z. (2013). Effect of weaning age on productive performance and some plasma biochemical parameters of Barki lambs in Siwa Oasis, Egypt. Global Veterinária, 10(2), 189-202. doi: 10.5829/ idosi.gv.2013.10.2.1104

Abdelrahman, M. M. (2012). Status of some minerals of growing Awassi lambs fed calcium salt fat and protected sulfur amino acid. Journal of Animal \& Plant Sciences, 13(1), 1698-1703.

Al-Haidary, A. A., Aljumaah, R. S., Alshaikh, M. A., Abdoun, K. A., Samara, E. M., Okab, A. B., \& Alfuraiji, M. M. (2012). Thermoregulatory and physiological responses of Najdi sheep exposed to environmental heat load prevailing in Saudi Arabia. Pakistan Veterinary Journal, 32(4), 515-519.

Aliyu, I. D., Maigandi, S. A., Muhammad, I. R., \& Garba, Y. (2012). Haematological indices and blood urea nitrogen of yankasa ram lambs fed urea, poultry droppings and or urea treated Pennisetum pedicellatum (Kyasuwa Grass). Nigerian Journal of Basic and Applied Science, 20(1), 39-43. 
Antunović, Z., Šperanda, M., \& Steiner, Z. (2004). The influence of age and the reproductive status to the blood indicators of the ewes. Archives Animal Breeding, 47(3), 265-273. doi: 10.5194/aab-47-265-2004

Astuti, D. A., Baba, A. S., \& Wibawan, I. W. T. (2012). Rumen fermentation, blood metabolites, and performance of sheep fed tropical browse plants. Media Peternakan, 34(3), 201-206. doi: 10.5398/ medpet.2011.34.3.201

Babu, B. S., Suryanarayana, M. V. A. N., Raghava Rao, E., \& Asha Latha, P. (2018). Effect of feed restriction on serum biochemical profile in ram lambs. International Journal of Current Microbiology and Applied Sciences, 7(3), 925-930. doi: 10.20546/ ijcmas.2018.703.109

Bacila, M. (2003). Bioquímica veterinária (2a ed.). São Paulo: Robe.

Borburema, J. B., Cezar, M. F., Marques, D. D., Cunha, M. G. G., Pereira, J. M., Fo., Sousa, W. H.,... Costa, R. G. (2012). Efeito do regime alimentar sobre o perfil metabólico de ovinos Santa Inês em confinamento. Arquivo Brasileiro de Medicina Veterinária eZootecnia, 64(4), 983-990. doi:10.1590/S 0102-09352012000400027

Carlos, M. M. L., Leite, J. H. G. M., Chaves, D. F., Vale, A. M., Façanha, D. A. E., Melo, M. M., \& Soto-Blanco, B. (2015). Blood parameters in the morada nova sheep: influence of age, sex and body condition score. The Journal of Animal \& Plant Sciences, 25(4), 950-955.

Chon, S., Lee, Y. J., Fraterrigo, G., Pozzilli, P., \& Choi, M. C. (2013). Evaluation of glycemic variability in well-controlled type 2 diabetes mellitus. Diabetes technology \& therapeutic, 15(6), 455-460. doi: 10. 1089/ dia.2012.0315

Cruz, R. E. S. da, Rocha, F. M., Sena, C. V. B., Noleto, P. G., Guimarães, E. C., Galo, J. A., \& Mundim, A. V. (2017). Effects of age and sex on blood biochemistry of Dorper lambs. Semina: Ciências Agrárias, 38(5), 30853093. doi: 10.5433/1679-0359.2017v38n 5 p3085

D'angelino, J. L., Ishizuka, M. M., Ribeiro, L., Tucci, T. V., \& Birgel, E. H. (1990). Valores padrões de constituintes bioquímicos do soro de caprinos sadios criados no Estado de São Paulo. Estudo da influência do fator etário. Brazilian Journal of Veterinary Research and Animal Science, 27(1), 91-97. doi: 10.11606/issn.0000-0000.27191-97

Friedewald, W. T., Lew, R. I., \& Fredrickson, D. S. (1972). Estimation of the concentration of low-density lipoprotein cholesterol in plasma, without the use of the preparative ultracentrifuge. Clinical Chemistry, 18(6), 499-502.

González, F. H. D. (2000). Uso de perfil metabólico para determinar o status nutricional em gado de corte. In F. H. D. González, J. O. Barcellos, H. Ospina, \& L. A. O. Ribeiro (Eds.), Perfil metabólico em ruminantes: seu uso em nutrição e doenças nutricionais. Porto Alegre: Gráfica da Universidade Federal do Rio Grande do Sul.

González, F. H. D., \& Scheffer, J. F. S. (2009). Perfil sanguíneo: ferramenta de análise clínica metabólica e nutricional. Avaliação metabólico nutricional de vacas leiteiras por meio de fluidos corporais (sangue, leite e urina). Anais do Congresso Nacional de Medicina Veterinária, Gramado, RS, Brasil, 29. 
Gouveia, L. N. F., Maciel, M. V., Soares, P. C., Silva, I. F., Neto, Gonçalves, D. N. A., Batista, A. M. V., \& Carvalho, F. F. R. (2015). Perfil metabólico de ovinos em crescimento alimentados com dietas constituídas de feno ou silagem de maniçoba e palma forrageira. Pesquisa Veterinária Brasileira, 35, 5-9. doi: 10.1590/S0100736X2015001300002

Gregory, L., Bardese, C. B., Birgel, E. H., Jr., Meira, E. B. S., Jr., Piva, F. M., \& Hasegawa, M. Y. (2009). Lipidograma e glicemia de caprinos da raça Saanen, durante os primeiros dias de vida. Arquivos Veterinaria, 25(3), 109115. doi: $10.15361 / 2175-0106.2009 v 25 n$ 3p109-115

Kaneko, J. J., Harvey, J. W., \& Bruss, M. L. (2008). Clinical biochemistry of domestic animals (6nd ed.). San Diego: Academic Press.

Kowalski, L. H., Souza, D. F., Monteiro, A. L. G., Fernandes, S. R., \& Silva, C. J. A. (2013). Indicadores da função hepática em cordeiros recém-nascidos, antes e após a ingestão de colostro. Synergismus Scyetifica, 8(2), 1-3.

Lima, F. G., Ribeiro, C. S., Andrade, D. D. F., Costa, G. L., Hugo, C. M., Guimaraes, V. Y.,... Fioravanti, M. C. S. (2012). Effects of Brachiaria brizantha Hay Containing a Steroidal Saponin in Lambs. IJPPR, 2, 2026.

Loste, A., Ramos, J. J., Fernández, A., Ferrer, L. M., Lacasta, D., Verde, M. T.,... Ortin, A. (2008). Effect of colostrum treated by heat on immunological parameters in newborn lambs. Livestock Science, 117(2-3), 176183. doi: 10.1016/j.livsci.2007.12.012

Mahjoubi, E., Yazdi, M. H., Aghaziarati, N., Noori, G. R., Afsarian, O., \& Baumgard, L. H.
(2015). The effect of cyclical and severe heat stress on growth performance and metabolism in Afshari lambs. Journal of Animal Science, 93(4), 1632-1640. doi: 10.2527/jas.2014-8641

Maurya, V. P., Sejian, V., \& Naqvi, S. M. K. (2013). Effect of cold stress on growth, physiological responses, blood metabolites and hormonal profile of native Malpura lambs under hot semi-arid tropics of India. Indian Journal of Animal Sciences, 83, 370-373.

Meira, E. B. de S., Jr., Rizzo, H., Benesi, F. J., \& Gregory, L. (2009). Influência dos fatores sexuais e etários sobre a proteína total, fração albumina e atividade sérica de aspartato-aminotransferase e gamaglutamiltransferase de ovinos da raça Santa Inês. Brazilian Journal of Veterinary Research and Animal Science, 46(6), 448. doi:10.11606/s1413-95962009000600003

Mugabe, L. C., Bagaldo, A. R., Barbosa, L. P., Araújo, F. L., Oliveira, B. Y. S., Silva, R. V. M. M.,... Pinheiro, E. E. G. (2017). Biochemical and seminal parameters of lambs fed palm kernel cake under grazing system. Revista Brasileira de Zootecnia, 46(8), 670-677. doi: 10.1590/s1806-92902017000800007

Njidda, A. A., Shuai, A. A., \& Isidahomen, C. E. (2014). Haematological and serum biochemical indices of sheep in semi-arid environment of northern nigeria. Global Journal of Science Frontier Research. D Agric. Vet, 14(4), 1-9.

Oliveira Franco, M. de, Detmann, E., Campos Valadares, S. de, Fo., Batista, E. D., Almeida Rufino, L. M. de, Barbosa, M. M., \& Lopes, A. R. (2017). Intake, digestibility, and rumen and metabolic characteristics of cattle fed low-quality tropical forage and 
supplemented with nitrogen and different levels of starch. Asian-Australasian Journal of Animal Sciences, 30(6), 797. doi: 10.5713/ajas.16.0629

Oramari, R. A. S., Bamerny, A. O., \& Zebari, H. M. H. (2013). Factors affecting some hematology and serum biochemical parameters in three indigenous sheep breeds. Advances in Life Science and Technology, 7181 (21), 56-63. doi: 10. 1007/s00580-004-0525-3

Peixoto, L. A. O., \& Osório, M. T. M. (2007). Perfil metabólico proteico e energético na avaliação do desempenho produtivo em ruminantes. Revista Brasileira Agrociência, 13(3), 299-304. doi: 10.18539/cast.v13i3. 1376

Pereira, E. S., Campos, A. C. N., Castelo-Branco, K. F., Bezerra, L. R., Gadelha, C. R. F., Silva, L. P.,... Oliveira, R. L. (2018). Impact of feed restriction, sexual class and age on the growth, blood metabolites and endocrine responses of hair lambs inatropical climate. Small Ruminant. Research., 158, 9-14. doi: 10.1016/j.smallrumres.2017.11.007

Rahman, M. K., Islam, S., Ferdous, J., Uddin, M. H., Hossain, M. B., Hassan, M. M., \& Islam, A. (2018). Determination of hematological and serum biochemical reference values for indigenous sheep (Ovies aries) in Dhaka and Chittagong Districts of Bangladesh. Veterinary World, 11(8), 1089-1093. doi: 10.14202/vetworld.2018.1089-1093

Ribeiro, L. A. B., González, F. H. D., Conceição, T. R., Brito, M. A., La Rosa, V. L., \& Campos, R. (2003). Perfil metabólico de borregas Corriedale em pastagem nativa do Rio Grande do Sul. Acta Scientiae Veterinariae, 31(3), 167-170. doi: 10.22456/1679-9216. 17161
Roubies, N., Panousis, N., Fytianou, A., Katsoulos, P. D., Giadinis, N., \& Karatzias, $H$. (2006). Effects of age and reproductive stage on certain serum biochemical parameters of chios sheep under greek rearing conditions. Journal of Veterinary Medicine Series A, 53(6), 277-281. doi: 10.1111/j.1439-0442.2006.00 832.x

Samra, M., \& Abcar, A. C. (2012). False estimates of elevated creatinine. The Permanente Journal, 16(2), 51-52.

Santos, R. P. dos, Macedo, G. D. L., Jr., Silva, S. P. da, Sousa, L. F. de, \& Andrade, M. E. B. (2017). Inclusion of propylene glycol in the diet of sheep and its effect on their lambs' protein and mineral metabolites. Acta Scientiarum. Animal Sciences, 39(3), 297. doi: 10.4025/actascianimsci.v39i3.35101

Santos, R. P. dos, Sousa, L. F., Sousa, J. T. L., Andrade, M. E. B., Macedo, G. L., Jr., \& Silva, S. P. (2015). Parâmetros sanguíneos de cordeiros em crescimento filhos de ovelhas suplementadas com níveis crescentes de propilenoglicol. Revista Brasileira de Ciências Agrárias, 10(3), 473478. doi: 10.5039/agraria.v10i3a4924

Sarwar, M., \& Shahzad, M. (2011). Performance of growing lambs receiving altered plant protein sources with or without probiotics. IPCBEE, 13, 139-144.

Schroder, B., Schoneberger, M., Rodehutscord, M., Pfeffer, E., \& Breves, G. (2003). Dietary protein reduction in sheep and goats: different effects on L-alanine and L-leucine transport across the brush-border membrane of jejunal enterocytes. Journal of Comparative Physiology B, 173(6), 511518. doi: 10.1007/s00360-003-0359-3 
Sejian, V., Bhatta, R., Gaughan, J., Malik, P. K., Naqvi, S. M. K., \& Lal, R. (2017). Adapting sheep production to climate change. In V. Sejian, R. Bhatta, J. Gaughan, P. Malik, S., Naqvi \& R. Lal (Eds.), Sheep Production Adapting to Climate Change (pp. 1-29). Springer, Singapore.

Shetaewi, M. M., \& Ross, T. T. (1991). Effects of concentrate supplementation and lasalocid on serum chemistry and hormone profiles in Rambouillet ewes. Small Ruminant. Research, 4(4), 365-377. doi: 10.1016/0921-4488(91)90082-2

Silva, E. R. R., Hunka, M. M., Ferreira, M. P. B., Almeida, T. L. A. C., Vaz, S. G., Mélo, S. K. M.,... Manso, H. C., Fo. (2017). Biomarcadores sanguíneos de caprinos Saanen com diferentes faixas etárias. Revista Brasileira de Ciência Veterinária, 24(1), 22-26. doi: 10.4322/rbcv.2017.005

Silva, R. G. da, Paranhos, M. J. R., \& Sobrinho, S. (1992). Influence of hot environments on some blood variables of sheep. International Journal of Biometeorology, 36(4), 223-225.

Solberg, H. E. (2006). RefVal 4.11 software user's guide. Rykkinn, Norway: RefVal.

Souza, D. F. de, Reijers, T. S. S. S., Gilaverte, S. Cruz, T. A. da, Hentz, F., Castilhos, B. de Q.,... Monteiro, A. L. G. (2020). Dynamics of biochemical parameters in lambs during the first four months of life. Revista Brasileira de Zootecnia, 49, 1-13. doi: 10. 37496/rbz4920190167
Stear, M. J., Eckersall, P. D., Graham, P. A., McKellar, Q. A., Mitchell, S., \& Bishop, S. C. (2001). Fructosamine concentration and resistance to natural, predominantly Teladorsagia circumcinctan infection. Parasitology, 123(2), 211-218.

Tripathi, M. K., Mondal, D., \& Karim, S. A. (2008). Growth, haematology, blood constituents and immunological status of lambs fed graded levels of animal feed grade damaged wheat as substitute of maize. Journal of Animal Physiology and Animal Nutrition, 92(1), 75-85. doi: 10.1111/j.1439 -0396. 2007.00712.x

Van Cleef, E. H. C. B., Almeida, M. T. C., Perez, H. L., Carvalho, V. B., \& Paschoaloto, J. R. (2016). Effects of high concentrations of crude glycerin on blood parameters of energy metabolism in finishing lambs. Journal of Animal Science, 94(5), 822. doi: 10.2527/jam2016-1687

Vivian, D. R., Garcez Neto, A. F. G., Freitas, J. A., Fernandes, S. R., \& Rozanski, S. (2017). Performance and serum chemistry profile of lambs fed on rations with increasing levels of urea. Semina: Ciências Agrárias, 38(2), 919-930. doi: 10. 5433/1679-0359.2017v38n2p919 
